University of Nebraska - Lincoln

DigitalCommons@University of Nebraska - Lincoln

8-1995

Domestic Structures and the Diversionary Use of Force

Ross A. Miller

University of Nebraska - Lincoln, rmiller10@unl.edu

Follow this and additional works at: https://digitalcommons.unl.edu/poliscifacpub

Part of the Political Science Commons

Miller, Ross A., "Domestic Structures and the Diversionary Use of Force" (1995). Faculty Publications:

Political Science. 51.

https://digitalcommons.unl.edu/poliscifacpub/51

This Article is brought to you for free and open access by the Political Science, Department of at DigitalCommons@University of Nebraska - Lincoln. It has been accepted for inclusion in Faculty Publications:

Political Science by an authorized administrator of DigitalCommons@University of Nebraska - Lincoln. 


\title{
Domestic Structures and the Diversionary Use of Force*
}

\author{
Ross A. Miller, Santa Clara University
}

Theory: This paper reformulates diversionary theory to take into account the effect of domestic structures on the propensity of leaders to use foreign policy to manipulate domestic politics.

Hypotheses: The structure of domestic political institutions and levels of policy resources condition the willingness of leaders to use conflict involvement to manipulate domestic audiences.

Method: Probit analysis of 294 militarized interstate disputes during the period from 1955 to 1976.

Results: Domestic structures have a significant effect on the propensity of leaders to use foreign policy as a vehicle of their personal political ambitions.

\section{Introduction}

Explanations of national decisions to use force have traditionally neglected the possible contribution of domestic political processes or institutions. "Domestic political variables," as Levy $(1988,79)$ observes, "are not included in any of the leading theories of the causes of war; instead, they appear only in a number of isolated hypotheses and in some empirical studies that are generally atheoretical and noncumulative." One reason for this neglect is that realism, arguably the dominant theoretical tradition of those who study international conflict, asserts that the primary factors determining foreign policy are found at the systemic level, often indicated by the distribution of military and economic power (Morgenthau 1967; Waltz 1959, 1979). ${ }^{1}$ In the realist view the distribution of power imposes a

\footnotetext{
*I am most grateful to Randy Siverson, Bob Jackman, Scott Gartner, Lewis Snider, Letitia Lawson and Steve Nicholson for their comments on this paper. I also wish to thank the editor and the anonymous referees for their suggestions. The data utilized are derived from four sources: the Militarized Interstate Dispute data set (Gochman and Maoz 1984), the Polity II data set (Gurr, Jaggers, and Moore 1989), Summers and Heston (1988), and the United Nations Statistical Yearbook (various years). Documentation necessary to replicate the analysis can be obtained from the author. This research was made possible by a grant from the Institute on Global Conflict and Cooperation, University of California, San Diego. An earlier version of this paper was presented at the annual meeting of the International Studies Association West, Monterey, CA.

'Although classical realists do not altogether dismiss domestic political factors, they assign them a secondary role compared to external constraints and opportunities. Neorealists
}

American Journal of Political Science, Vol. 39, No. 3, August 1995, Pp. 760-785

(C) 1995 by the Board of Regents of the University of Wisconsin System 
structure that constrains foreign policy elites to such an extent that domestic political considerations are relatively unimportant in shaping their policy choices.

In recent years, however, the effect of domestic factors on state foreign policy has generated substantial research generally focused on two areas. ${ }^{2}$ The first stems from the broadly based empirical finding that while democracies are just as war-prone as other types of states (Small and Singer 1976; Chan 1984; Weede 1984), they simply do not engage each other in conflicts of sufficient severity to be counted as international wars (Maoz and Abdolali 1989).

Second, and coinciding with the research on regime type and war, is a renewed interest in diversionary theory. In its simplest form, diversionary (or scapegoat) theory argues that leaders of nation-states use foreign conflict involvement to divert domestic attention from internal problems (see Blainey 1988 and Levy 1989 for critiques). While the initial exploratory analyses yielded few significant results (Rummel 1963; Tanter 1966; Wilkenfeld 1972), recent studies using different research designs have found a modest link between leader popularity and the diversionary use of force (Ostrom and Job 1986; James and Oneal 1991; Morgan and Bickers 1992).

This paper seeks to expand our theoretical and empirical knowledge of the relationship between domestic politics and foreign policy by specifying the relationships among domestic variables and their consequent effects on foreign policy. In particular, I focus on the effect of domestic structures and systemic forces on the response of leaders to military threats from abroad. Following a discussion of the interrelationships among domestic and international sources of foreign policy, I evaluate their explanatory power using a set of 294 militarized interstate disputes that occurred between 1955 and 1976.

\section{Theoretical and Empirical Issues}

The contention that leaders use international conflict to divert attention from domestic political problems is hardly novel (see Haas and Whiting

place an even stronger emphasis on systemic factors. According to Waltz $(1959,160)$ : “Because any state may at any time use force, all states must constantly be ready either to counter force with force or to pay the cost of weakness. The requirements of state action are, in this view, imposed by the circumstances in which all states exist."

${ }^{2}$ These studies include, among others, Bueno de Mesquita and Lalman (1992), Gaubatz (1991), James and Oneal (1991), Maoz and Abdolali (1989), Maoz and Russett (1993), Morgan and Campbell (1991), Morgan and Bickers (1992), Ostrom and Job (1986), Russett (1987, 1990), and Siverson and Starr (1994). 
1956; Wright 1965). Initial analyses of the relationship between domestic turmoil and the propensity of states to engage in international conflict concluded that the relationship is weak to nonexistent. Rummel (1963) found little relationship among nine indicators of domestic conflict and 13 indicators of foreign conflict; attempts to replicate Rummel's analysis using slightly different approaches reached similar conclusions (Tanter 1966; Haas 1968; Wilkenfeld 1972; Kegley, Richardson, and Richter 1978). Other studies found some evidence linking domestic political problems and the external use of force by controlling for governmental structure (Wilkenfeld 1968; Zinnes and Wilkenfeld 1971), the degree of militarization of the state (Kegley, Richter, and Richardson 1978), and ethnic diversity (Hazelwood 1973).

The general lack of support for diversionary theory found in these earlier studies is at odds with recent empirical work using different research designs, which finds a relatively strong relationship between leader popularity and the political use of force. In one of the first studies in this genre, Ostrom and Job (1986) evaluated the relative effect of systemic and domestic factors on the propensity of U.S. presidents to use military force abroad. Their results indicate that popularity levels have a stronger effect on the probability that a U.S. president will initiate the use of force than any of the international variables: When popularity levels fall below .43, "in the absence of other factors the president is unlikely to use force at all." But when popularity levels are between .43 and .58 , "the president may use force in anticipation of being able subsequently to regain some of his lost approval" (Ostrom and Job 1986, 558). In their reanalysis of Ostrom and Job, James and Oneal $(1991,307)$ conclude that "domestic political factors remain most consequential in the president's decision to use force short of war.' Similarly, Morgan and Bickers (1992) examined the relationship between support for presidents within their ruling coalitions and their propensity to use military force. Their results suggest that between 1953 and 1976, American presidents were "more prone to initiate aggressive foreign policy actions when the president was faced with a loss of support among his partisans"' (Morgan and Bickers 1992, 49).

How can we account for the different conclusions drawn by the initial and the recent tests of diversionary theory? One explanation is that the relationship may be unique to the United States, or to those nations that share a particular trait of the United States. Russett (1990, 130-131), for example, found a significant relationship between changing economic conditions and the dispute behavior of major powers, but found no relationship for minor powers. Thus, the relationship between leader popularity and the diversionary use of force may be restricted to major powers.

Alternatively, these results may reflect different research designs. The 
newer studies all use time-series analyses of the United States, while the earlier studies employed cross-sectional designs that include a much larger number of nations, but generally cover a shorter time period. As Morgan and Bickers $(1992,34)$ contend, perhaps "the hypothesis requires a research design that is longitudinal, not cross-sectional."

I address this puzzle in three ways. First, I argue that the inconsistencies found between the results of time-series and cross-sectional tests of diversionary theory are due to the way the theory is specified, and not simply a function of variations in research design. I respecify the relationship between leader popularity and the political use of force to take into account cross-national differences in domestic structures. In my approach, the propensity of leaders to use foreign policy to manipulate domestic audiences is conditioned by the structure of domestic political institutions and the level of policy resources available to leaders. Second, I control for the effect of system-level factors on the relationship between leader popularity and national decisions to use force. Finally, I evaluate the ability of the reformulated theory to account for the response of leaders to demands placed by other states that are backed with the threat, display or use of military force. Although the existing literature on diversionary theory focuses on the relationship between leader popularity and the initiation of international conflict, if the theory is generalizable beyond conflict initiation it should provide a reasonable guide for the reformulation presented below.

\section{Theoretical Reformulation}

A variety of theoretical specifications have been used in empirical evaluations of diversionary theory. According to Morgan and Bickers (1992, 28 ), the diversionary hypothesis has generally been treated as "a universal dictum of state behavior rather than as a partial explanation of some foreign policy decisions." My reformulation builds on the second idea, and makes three basic assumptions. First, I assume that leaders in power wish to maintain power and that leaders need the support of others to do so. ${ }^{3}$ In some states this may involve a diverse coalition of interest groups and political parties, while in other states it may involve the support of the military and the bureaucracy, or some other combination of groups. Whatever the particular coalition, all leaders share one fundamental reality: their political futures depend on the implementation of foreign and domestic policies that are viewed favorably by the group(s) whose support they rely on. Thus, policy outcomes (What have you done for me lately?) play a critical role in determining the fate of regimes. Leaders are not altruists; the implementation of policies that benefit supporters is a pragmatic approach to power

\footnotetext{
${ }^{3}$ This section draws from Bueno de Mesquita and Siverson (1993).
} 
maintenance. The assumption that leaders in power wish to maintain power does not preclude leaders from pursuing other preferences; it simply states that the primary preference of leaders is to stay in power. ${ }^{4}$

I further assume that all leaders can be removed from power. The mechanisms for removing leaders vary: in some states regularly scheduled elections offer groups a means of altering regimes, while in other states coups d'etat and assassinations are more commonly used. But all leaders, regardless of the structure of domestic political institutions, can in one way or another be held accountable for their performance by the groups that help them acquire power.

A final assumption is that leaders base foreign policy decisions on domestic and international concerns (Lindsay, Sayrs, and Steger 1992). In this vein, international politics is linkage politics: foreign policies are affected by domestic and international factors, and they may be intended to influence domestic and international audiences. For purposes of empirical evaluation, the systemic level is indicated by the level of hostility of the state that placed the demand and the relative power of the dispute participants. These two variables represent the international context in which the dispute takes place. The domestic variables include the popularity of the leaders, the policy resources available to leaders, and the structure of domestic political institutions. These variables represent the willingness of leaders to employ diversionary tactics. The latter two domestic variables condition the effect of popularity level on the leader's response to threats from abroad. I discuss each variable in turn.

\section{System-level Variables}

Realists contend that the international system is the primary source of state foreign policies. To survive, states must respond to the policies and changing capabilities of the other states in the international system (Waltz 1959, 1979). Studies by Leng and Wheeler (1979), Leng (1983), and Huth and Russett (1988) show that the bargaining strategies employed by nations involved in a dispute influence the outcome of that dispute. The use of bullying strategies (i.e., those characterized by high levels of hostility) by either dispute participant is systematically related to the escalation of that dispute to war. Ostrom and Job (1986) and James and Oneal (1991) include in their analyses a measure of the "level of international tension" between the United States and the Soviet Union. Ostrom and Job $(1986,546)$ argue that, "the higher the existing tensions between the superpowers, the more likely it will be for the president to consider acting in a forceful manner."

\footnotetext{
${ }^{4}$ Of course, I also assume that leaders act rationally. On this point, see Bueno de Mesquita (1981), Jackman (1993), and Riker (1990).
} 
Both studies conclude that the level of international tension has a significant effect on the probability that a U.S. president will initiate the use of force. This leads to:

Hypothesis 1: The higher the level of hostility of the initiator, the higher the probability that leaders respond with force.

A second factor emphasized by system theorists to explain interstate behavior is the relative capability of nation-states. According to realists such as Morgenthau (1967) and Waltz (1979), balances of power lead to peace, whereas imbalances of power lead to war. Balances of power reduce the probability of war because they reduce the possibility that either side can achieve victory if war occurs. The greater the level of preponderance, the higher the probability of victory for the stronger power, and therefore the higher the probability that the latter will initiate or escalate a dispute.

On the other hand, theorists such as Organski (1968), Organski and Kugler (1980), and Gilpin (1981) contend that power preponderance leads to peace, while balances of power are associated with war. Power preponderance theories contend that leaders of relatively weak states are likely to cave in to the demands of their stronger counterparts and should be reluctant to press their demands against stronger states in order to avoid the possibility of international conflict. As a consequence, disputes between and among equals are more likely to escalate than disputes characterized by large differences in capabilities, since it is under the former condition that both states believe they will prevail in a war.

Siverson and Tennefoss $(1984,1061)$ assess the relative merits of the two contrasting theories. Their analysis of 255 dyadic conflicts between 1816 and 1965 that had at least one major power participant indicates that conflicts among unequals were more likely to escalate than conflicts involving states of approximately equal capabilities. Moul $(1988,242)$ has also examined this question, among the European great powers, from 1815 to 1939 , and concludes that "conflicts between approximately equal, nonseparated great power opponents were much more likely to escalate to war than were conflicts between unequals."

The balance of power and power preponderance schools suggest two competing hypotheses:

Hypothesis 2: The greater the relative capability of the target, the higher the probability the target responds with force.

Hypothesis 3: The more equivalent the relative capabilities of the initiator and the target, the higher the probability the target responds with force. 


\section{Domestic-level Variables}

Central to diversionary theory is the notion that leaders use foreign policy to manipulate domestic support. Changes in levels of support are therefore critical to predicting the probability that leaders will use diversionary tactics: the lower the level of support, the higher the probability that leaders will engage in international conflict. Most versions of diversionary theory do not take into account factors that affect the willingness of leaders to use international conflict involvement to manipulate their popularity. Two factors that I believe influence the propensity of leaders to resort to diversionary measures are the policy resources available to leaders and the structure of domestic political institutions.

I argue that leaders facing declining levels of support prefer to implement policies that address the cause of their decline to diversionary policies. Although empirical evidence exists that the diversionary use of force produces a "rally around the flag effect" at home, this effect is short-lived (Mueller 1973; Brody 1984; Ostrom and Job 1986). Diversionary tactics are therefore, at best, short-term remedies for declining levels of support. Moreover, diversionary policies carry with them the risk of escalation, and national involvement in wars can have dire consequences for the responsible leaders (Bueno de Mesquita, Siverson, and Woller 1992). Finally, diversionary measures do not address the source of leaders' declining support. Given a choice between using diversionary tactics and implementing policies that remedy the cause of their decline, leaders should prefer the latter, for the reasons advanced above.

The capacity of governments to extract the necessary resources to implement policies that benefit supporters varies dramatically across states (Organski and Kugler 1980, 72). These differences have important implications for the fate of regimes. According to Organski and Kugler $(1980,74)$, the "failure to impose and extract taxes is one of the essential indicators of governmental incapacity to obtain and maintain support." Therefore, other things equal, the greater the capacity of leaders to extract resources, the lower the probability they will resort to diversionary tactics to manipulate domestic audiences. ${ }^{5}$

${ }^{5}$ Low levels of national political capacity may produce regimes that are dependent on a relatively small number of individuals (e.g., a military regime). Even though a leader may have few resources available to affect his or her popularity levels, these resources may be sufficient to correct for the cause of the leader's decline, thereby removing the need to use diversionary tactics. To control for the effects of the size of the ruling coalition on the relationship between levels of policy resources and the propensity of leaders to use diversionary tactics I include a measure of regime type in the model. Bollen $(1990,9)$ for example defines political democracy as "the extent to which the political power of the elites is minimized and that of the nonelites is maximized. By political power I am referring to the ability 
A second domestic variable that I believe conditions the willingness of leaders to use diversionary tactics is the structure of domestic political institutions. Kant was perhaps the first to argue that regime type affects the foreign policy behavior of states:

if ... the consent of the citizens is required in order to decide whether there should be war or not, nothing is more natural than that those who would have to decide to undergo all deprivations of war will very much hesitate to start such an evil game. ${ }^{6}$

While most research indicates that democracies are just as war-prone as nondemocracies (Small and Singer 1976; Chan 1984; Weede 1984; Maoz and Abdolali 1989), Morgan and Campbell (1991) show that political institutions affect the foreign policy behavior of leaders. They find that, for major powers, high levels of decisional constraints have a negative effect on the probability that a conflict will escalate to war (Morgan and Campbell 1991, 210). Similarly, Bueno de Mesquita and Lalman (1992) explore the question of whether democratic leaders have different expectations about the domestic political costs of using force than their autocratic counterparts. After examining 707 dispute dyads, Bueno de Mesquita and Lalman (1992, 155) conclude "the common and crucial assumption that democratic leaders anticipate, on average, higher domestic political costs for the use of force than do nondemocratic leaders is supported by the evidence."

I propose that the structure of domestic political institutions influences the propensity of leaders to use conflict involvement to manipulate domestic audiences. Leaders are treated as rational politicians whose primary goal is to stay in power, but their willingness to use diversionary tactics is affected by the anticipated domestic political costs of their actions. All other things being equal, if autocratic leaders expect to incur fewer domestic political costs for the use of force, they should be more willing than their democratic counterparts to employ diversionary tactics. ${ }^{7}$

[of elites] to control the national governing system." In this way, the level of autocracy can serve as a proxy for the size of the ruling coalition.

${ }^{6}$ Kant, Immanuel. 1977. The Philosophy of Kant: Immanuel Kant's Moral and Political Writings. Trans. C. Friedrich. New York: Modern Library, p. 438. Cited in Bueno de Mesquita and Lalman $(1992,153)$.

${ }^{7}$ Implicit in this argument is the assumption that the expected political benefit of diversionary behavior is the same for all leaders, regardless of regime type. As I noted above, the available empirical evidence indicates that the use of force produces a short-term rally around the flag effect for democratic leaders. However, systematic empirical evidence on the effect of the use of force on domestic support for autocratic leaders is lacking. Anecdotal evidence (such as the Falklands War) suggests that autocratic leaders expect domestic political benefits from the political use of force, but this does not give a precise comparison of 
The above discussion suggests three additional hypotheses:

HyPOTHESIS 4: Controlling for levels of policy resources and the structure of domestic political institutions, the lower the popularity of leaders, the higher the probability they respond with force.

HyPOTHESIS 5: The greater the level of policy resources available to leaders, the stronger the negative relationship between leader popularity and the probability that leaders respond with force.

HyPOTHESIS 6: The higher the level of autocracy, the stronger the negative relationship between leader popularity and the probability that leaders respond with force.

\section{Measures}

Leader response, the dependent variable, is based on a measure included in the Gochman and Maoz (1984) Militarized Interstate Dispute data set which indicates the highest level of hostility reached by the target of the demand during the dispute. Five possible responses are coded: (1) no codable action, (2) threat to use force, (3) display of force, (4) use of force, and (5) war. This variable represents a five-point, monotonic scale of increasing levels of hostility.

In its original form, the Gochman-Maoz (1984) indicator could be used to test for a linear relationship between leader popularity and the use of force. As Morgan and Bickers $(1992,34)$ point out, however, "we should not expect a linear relationship between some measure of the amount of domestic political problems and the amount of foreign conflict." Instead, we expect the probability that a leader will employ diversionary tactics to increase as the popularity of that leader erodes. Thus, diversionary behavior is expected after a leader's popularity drops below a threshold. In this approach, the degree to which the leader's popularity falls below the threshold does not influence the level of hostility of the target. I therefore use a nonlinear statistical model and a dichotomous dependent variable to evaluate the effects of leader popularity on the probability of the use of force.

Target responses are coded 1 if the response involves the use of force

leaders' expected utilities for the use of force. The empirical analysis presented below bears on this question. If democratic leaders expect greater domestic political benefits from using diversionary tactics than autocratic leaders, and if they face higher domestic political costs for using force than their autocratic counterparts, there should be no appreciable difference between the propensity of democratic and autocratic leaders to use conflict to manipulate domestic audiences. 
or war; and 0 for all responses that did not involve the use of force. ${ }^{8}$ The use of force is used as a cutoff for two reasons. First, as I mentioned earlier, theoretical and empirical research by Bueno de Mesquita and Lalman (1992) indicates that democratic leaders face higher domestic political costs for the use of force than leaders of autocracies. No existing research links domestic political costs with regime type at lower levels of hostility. Second, the distribution of the Gochman-Maoz indicator is bimodal: level 1 ("no codable action") and level 4 ("use of force") account for $70.7 \%$ of all observations (31.29\% and $39.46 \%$, respectively) used in the analyses presented below. On the other hand, level 2 ("threat") and level 3 ("display of force'') account together for only $23.4 \%$ of the cases $(6.8 \%$ and $16.6 \%$, respectively). ${ }^{9}$

Initiator hostility levels is drawn directly from the Gochman-Maoz (1984) data set. The initiator's actions are coded on a scale that is identical to the one used to indicate the actions of the target. Hypothesis 1 proposes a positive, monotonic relationship between hostility levels and the probability of the use of force. Therefore, in contrast to the method used to construct the dependent variable, it is unnecessary to dichotomize initiator hostility levels.

${ }^{8}$ I include wars in the construction of the dependent variable because the Gochman and Maoz (1984) measure of hostility is coded as the highest level of hostility used during the entire dispute. The ex post nature of the indicator suggests that it is entirely possible that the dispute participants initially used low levels of violence, and that the conflict escalated as each responded to the actions of the other (e.g. conflict spiral). There is no ex ante reason to believe that a state pursing diversionary behavior will be more likely to acquiesce under these conditions than another type of state. To ensure that the inclusion of wars was not biasing my results, I estimated a separate set of models (identical to those presented below) that excluded those cases where the target responded with war. The results were virtually identical to the models presented in Table 1 .

${ }^{9}$ To investigate the robustness of my results, I reestimated the models presented below with a dependent variable coded as 0 for hostility levels 1 and 2 ("no codable action" and "the threat of force," respectively) and 1 for hostility levels 3 through 5 ("display of force,"

"use of force," and "war," respectively). Substantively, the results with this alternative coding rule were very similar to those obtained using the first coding rule.

A second possible concern is selection bias. As Blainey $(1988,86)$ explains, "the spread of civil strife within a nation often resembled the death of a king; the royal funeral bells in the eighteenth century often had the same martial echoes as the bells that rang the curfew in troubled lands in later centuries. Both bells invited an enemy to attack.' In this vein, to focus on targets may be selecting those leaders who face domestic problems already, and are therefore more likely to respond with the use of force. This form of potential selection bias implies that the mean of the popularity variable should be a significant negative value, and the distribution of cases across the dependent variable should be skewed in favor a response involving the use of force. However, the mean of the indicator of popularity is -0.004 (see footnote 18 for additional summary statistics), and the distribution of cases across the categories of the response variable is $49 \%$ and $51 \%$ for 0 and 1 , respectively. Therefore, I do not believe that selection bias is a significant problem. 
Relative capability is measured by calculating the percentage difference in real gross domestic product between the target and the initiator. Although other measures have been used to assess relative capabilities, aggregate economic indicators (such as gross national product) perform reasonably well as indicators of overall capability (James 1987, 589)..$^{10}$

Leader popularity is perhaps the most difficult of all the variables to measure. Recent empirical research on the link between leader popularity and the diversionary use of force is limited to democratic systems (mainly, the United States). One reason for this limited spatial domain is the availability of information on the popularity of leaders across nations. For U.S. leaders, reliable survey data are available from the early postwar period to the present, allowing for detailed time series analyses. To evaluate the conditioning effects of regime type and policy resources on the relationship between leader popularity and the diversionary use of force requires a much larger spatial domain. The primary difficulty is developing an indicator of popularity in the absence of direct survey data. I use economic-policy outcomes to assess the popularity of leaders. While one can imagine alternative measures, economic-policy outcomes are difficult for governments to hide and relatively easy for individuals to evaluate. Economic-policy failures are felt directly through higher prices, higher unemployment, and a lower standard of living. Moreover, empirical evidence suggests a relatively strong link between economic-policy outcomes and leader popularity in the United States (Brace and Hinckley 1992; Beck 1991; Norpoth 1991; Hibbs 1982; Ostrom and Simon 1985), West Germany (Kirchgassner 1991), France (Lafay 1991), and Great Britain (Norpoth 1991).

One concern may be the extent to which the domestic support for $a u$ thoritarian regimes is affected by changes in economic conditions. After evaluating the effect of a one-year lag of the difference in annual growth rates of per capita real gross domestic product on the incidence of coups

\footnotetext{
${ }^{10}$ As a test of the validity of using real gross domestic product as an indicator of power, I estimated a probit model to evaluate the ability of this indicator to predict the power status (major-minor power) of the targets and initiators involved in disputes between 1950 and 1976. The percentage of states correctly classified is $95.6 \%(N=483)$ and $94.0 \%(N=$ 473), respectively.

I also investigated the possible effects of allies on target decisions. To this end, I estimated models that included four alliance measures: the number of major power allies on the side of the target and the initiator; and the total number of allies on the side of the initiator and the target. Of these four variables, only the number of major power allies on the side of the initiator was statistically significant. More importantly, alliance membership had no substantive effect on the estimate for leader popularity in any of the models presented below.
} 
for 121 countries from 1950 to 1982, Londregan and Poole (1990 178, emphasis added) conclude:

The coup-inhibiting effect of income is dramatic. For this reason, even authoritarian governments have powerful incentives to promote economic growth, not out of concern for their citizens, but because failure to deliver adequate economic performance may lead to their downfall. ${ }^{11}$

Below, the popularity of leaders is indicated by the difference between the growth rate of per capita real gross domestic product in the year before the dispute (t-1) and the average growth rate of per capita real gross domestic product during the previous five years ( $\mathrm{t}-6$ to $\mathrm{t}-2) .{ }^{12} \mathrm{I}$ focus on changes in growth rates in order to have a baseline against which to judge the performance of leaders (Summer and Heston 1988). ${ }^{13}$ Levels of policy resources can be indicated by a number of factors. I use the structure of the government's revenue base - the proportion of total central government revenue derived from direct taxes - to indicate levels of policy resources (United Nations Statistical Yearbook). ${ }^{14}$ Although governments use a variety of methods to raise revenue, generally there are two types: revenue bases that primarily consist of taxes on imports and exports, and those that tend to rely on direct taxes.

Import and export taxes are relatively easy to implement. This path of least resistance is attractive to governments because it allows them to extract resources from society with minimal effort. Simplicity, however, is purchased at the price of security. Import and export taxes are based on the sale or purchase of commodities and are influenced by the supply and demand for those commodities. The amount of revenue generated in any given year is therefore sensitive to economic shocks at home and abroad. This not only translates into a less secure revenue base, it also means less

${ }^{11}$ I do not wish to imply that changing economic conditions affect all leaders in an identical manner. It is reasonable to argue, for example, that the popularity levels of authoritarian leaders in socialist countries may be affected to a lesser degree than the popularity levels of leaders in capitalist democracies. This, I believe, is a valid criticism of the indicator. Nevertheless, I am unaware of an alternative indicator of leader popularity that is superior to the one used here.

${ }^{12}$ If the dispute occurred by September 1 or later, I used the growth rate for that year. If it occurred prior to this date, I used the growth rate for the prior year.

${ }^{13}$ Analyses were also done using an indicator based on the first difference of growth rates. Substantively, the results were virtually identical to those using the five year average as the baseline.

${ }^{14}$ To make the measure comparable temporally and spatially, it was necessary to include the following in the measure of direct taxes: social security contributions, property taxes, and death taxes. 
manipulative capability during times of need. The price of most commodities is elastic (and for many of them substitutes exist), and increasing the amount of the tax on the commodity will only result in a decrease in demand.

Direct taxes provide a more manipulable, more secure base of revenue. Unlike taxes on exports and imports, direct taxes can be increased without a concomitant decrease in the number of units being taxed. Furthermore, leaders can use direct-tax policies to reward supporters and punish political rivals by altering the rate at which segments of society are taxed. Import and export taxes do not offer this flexibility: they can be decreased relatively easily, but increasing them has little effect on overall levels of revenue if the demand for the commodity is price-elastic. In addition, countries that have developed the bureaucracy necessary for a revenue base relying on direct taxes are likely to have other policies at their disposal, such as unemployment insurance and welfare programs. Unemployment insurance and welfare programs help mitigate the effects of changing economic conditions on leaders' popularity levels. During periods of economic recession leaders can extend unemployment insurance coverage or expand welfare benefits to reduce the burden on society. This has two effects: it improves the living conditions of unemployed workers, and it stimulates the economy, thereby helping the nation to recover from the recession. ${ }^{15}$

Level of autocracy is drawn from the Polity II data set (Gurr, Jaggers, and Moore 1989). ${ }^{16}$ The indicator is an additive, weighted 11-point scale with 0 representing the lowest level of autocracy and 10 representing the highest level of autocracy. In Polity II, autocracy is defined as the degree to which state political institutions restrict or suppress competitive political participation. Five indicators are used to construct the scale: the competitiveness of political participation, the regulation of participation, the openness and competitiveness of executive recruitment, and constraints on the chief executive (Gurr, Jaggers, and Moore 1989, 37). ${ }^{17}$

The data set covers 294 militarized interstate disputes between 1955 and 1976 for which data were available. The spatial domain includes 58

\footnotetext{
${ }^{15}$ To evaluate the relationship between the revenue base and the probability that a state has in place an unemployment-insurance program, I used the the indicator of policy resources to predict whether a nation had an unemployment insurance program in place at the time of the dispute (United States Department of Health and Human Services 1983). The probit model correctly classifies $88.7 \%$ of the nations involved in disputes between 1952 and 1976 $(N=428)$.

${ }^{16} \mathrm{I}$ am most grateful to Kevin Wang and James Ray for providing the Polity II data.

${ }^{17}$ The Polity II Data set also includes a measure of democracy, which is highly correlated with autocracy (.85). To ensure comparability, models were also estimated substituting the measure of democracy for the measure of autocracy. The results were virtually identical.
} 
DOMESTIC STRUCTURES AND THE DIVERSIONARY USE OF FORCE

Table 1. Probit Coefficients for the Basic and Constrained Models (Coefficients [t-Ratios])

\begin{tabular}{|c|c|c|c|c|c|}
\hline \multirow[b]{2}{*}{ Variable } & \multirow{2}{*}{$\frac{\begin{array}{c}\text { Basic } \\
\text { Model }\end{array}}{1}$} & \multicolumn{2}{|c|}{ Policy Resources } & \multicolumn{2}{|c|}{ Autocracy Level } \\
\hline & & $\begin{array}{c}\text { Low } \\
2\end{array}$ & $\begin{array}{c}\text { High } \\
3\end{array}$ & $\begin{array}{c}\text { Low } \\
4\end{array}$ & $\begin{array}{c}\text { High } \\
5\end{array}$ \\
\hline $\begin{array}{l}\text { Initiator hostility } \\
\text { level }\end{array}$ & $\begin{array}{c}0.53^{*} \\
(5.24)\end{array}$ & $\begin{array}{c}0.67 * \\
(5.69)\end{array}$ & $\begin{array}{r}-0.18 \\
(0.09)\end{array}$ & $\begin{array}{c}0.33^{*} \\
(2.66)\end{array}$ & $\begin{array}{r}0.91 * \\
(4.33)\end{array}$ \\
\hline Target capability & $\begin{array}{c}-0.84^{*} \\
(2.35)\end{array}$ & $\begin{array}{c}-0.81^{*} \\
(2.00)\end{array}$ & $\begin{array}{c}0.24 \\
(0.24)\end{array}$ & $\begin{array}{c}-0.30 \\
(0.64)\end{array}$ & $\begin{array}{c}-1.48^{*} \\
(2.26)\end{array}$ \\
\hline Leader popularity & $\begin{array}{c}-3.00^{*} \\
(2.16)\end{array}$ & $\begin{array}{c}-3.50^{*} \\
(2.31)\end{array}$ & $\begin{array}{c}5.46 \\
(1.11)\end{array}$ & $\begin{array}{c}-1.58 \\
(0.92)\end{array}$ & $\begin{array}{r}-4.94 * \\
(2.15)\end{array}$ \\
\hline Level of autocracy & $\begin{array}{c}-0.01 \\
(0.35)\end{array}$ & $\begin{array}{c}-0.02 \\
(0.78)\end{array}$ & $\begin{array}{c}0.08 \\
(0.31)\end{array}$ & - & - \\
\hline $\begin{array}{l}\text { Level of policy } \\
\text { resources }\end{array}$ & $\begin{array}{c}-0.85^{*} \\
(2.08)\end{array}$ & - & - & $\begin{array}{c}-1.34^{*} \\
(3.06)\end{array}$ & $\begin{array}{c}1.21 \\
(0.98)\end{array}$ \\
\hline Log likelihood & -177.8 & -135.7 & -34.7 & -107.3 & -64.1 \\
\hline$N$ & 294 & 228 & 66 & 175 & 119 \\
\hline Chi-square & $49.32 *$ & $44.40 *$ & 01.38 & $23.77^{*}$ & $36.80 *$ \\
\hline $\begin{array}{l}\% \text { of cases correctly } \\
\text { classified }\end{array}$ & 70 & 70 & 77 & 70 & 75 \\
\hline
\end{tabular}

*Significant at $p<.05$ level using a two-tailed test.

countries that were the targets of a threat, display, or use of force by another nation-state. ${ }^{18}$

\section{Analysis}

Table 1 presents estimates from a multivariate probit analysis (Aldrich and Nelson 1984). Hypothesis 1 is strongly supported by the evidence: the coefficient for the level of hostility of the initiator is significant beyond the $p<.05$ level and the sign of the coefficient is positive, meaning that the higher the level of hostility of the initiator, the greater the probability

\begin{tabular}{|c|c|c|c|c|c|c|c|c|c|}
\hline Variable & Mean & $\begin{array}{c}\text { Std. } \\
\text { Deviation }\end{array}$ & Min & $\operatorname{Max}$ & 1 & 2 & 3 & 4 & 5 \\
\hline 1. hostility level & 3.63 & 0.84 & 1 & 5 & 1.00 & & & & \\
\hline 2. relative capability & 0.00 & 0.23 & -.88 & .46 & 0.02 & 1.00 & & & \\
\hline 3. leader popularity & 0.00 & 0.06 & -.40 & .20 & 3. 0.04 & -0.06 & 1.00 & & \\
\hline 4. policy resources & 0.31 & 0.24 & .04 & .91 & 4. -0.04 & 0.33 & 0.01 & 1.00 & \\
\hline $\begin{array}{l}\text { 5. autocracy level } \\
(N=294)\end{array}$ & 3.39 & 3.46 & 0 & 10 & $\begin{array}{l}5 .-0.01 \\
(N=294)\end{array}$ & -0.15 & 0.00 & -0.55 & 1.00 \\
\hline
\end{tabular}


that the target responds with force. The coefficient for the relative capability of the target is also statistically significant. The negative sign offers some support for Hypothesis 3, that power preponderance leads to peace. To make any firm judgements about the hypothesis, however, requires a disaggregation of the effects of relative capability (see Table 2 below). The results for leader popularity provide support for Hypothesis 4. The estimates in column 1 point to a negative relationship between leader popularity and target response, with the effects of the systemic and other domestic factors controlled. The sign of the coefficient estimate suggests that the lower the popularity of leaders, the more likely they are to respond with force. ${ }^{19}$

What is the relative importance of each variable in predicting whether or not a leader responds with force? One way to assess the relative contribution of the key independent variables is to compute the proportionate reduction of error obtained by adding each variable to the model (Goodman and Kruskal 1954). ${ }^{20}$ The level of hostility of the initiator dramatically improves the ability of the probit model to classify cases correctly. Its inclusion improves the model's performance by approximately $40 \%$. This provides additional evidence that reciprocity is a common feature of international politics. In contrast, the contribution of relative capability to the model's ability to successfully classify cases is slight-only about $2 \%$. Leader popularity improves the classification of cases by $8 \%$. The modest contribution of leader popularity to the explanatory power of the model provides support for the arguments of Morgan and Bickers $(1992,28)$, that the diversionary hypothesis should be treated as a "partial explanation of some foreign policy decisions," rather than "a universal dictum of state behavior."

Following Nagler (1991), I employ a strategy for assessing the degree to which levels of policy resources and autocracy condition the effect of leader popularity on target response. Nagler suggests restricting the values of the independent variables and comparing the results of separate models estimated using these restricted samples. Accordingly, I estimate four models, selecting the middle value of the indicators for levels of policy resources (.5) and level of autocracy (5) to evaluate their conditioning effects

\footnotetext{
${ }^{19}$ Level of policy resources has a negative, significant effect on the probability that the target will respond with force. This implies that the lower the level of policy resources available to leaders, the higher the probability that they will respond with force. The consequences of this are not readily apparent, since levels of policy resources is included in the model to condition the effects of leader popularity on target response, and not for its independent effects on target response.

${ }^{20}$ The proportionate reduction of error is calculated by dividing the difference between the prediction error that is obtained using a set of $k$ variables and the prediction error using $k+1$ variables by the prediction error from the original set of $k$ variables. This provides a statistic that varies from 0 to 1 .
} 
on leader popularity. In the test of the indicator-representing levels of policy resources, I compare the effect of leader popularity on response for leaders with low levels of policy resources with the effect of leader popularity on target response for leaders who possess high levels of policy resources. A similar test is done comparing the effects of leader popularity on target response for leaders who face relatively low domestic political costs for the use of force with the responses of leaders who face relatively high domestic political costs for the use of force. If Hypothesis 2 is correct, leader popularity should have a much stronger negative effect on the probability that the target will respond with the use of force for leaders with low levels of policy resources than for leaders with relatively high levels of policy resources. Similarly, leader popularity should have a more pronounced negative effect on leaders who face relatively low probabilities of removal for policy failures than on leaders who face relatively high probabilities of removal for policy failure. Columns 2 to 5 in Table 1 report the estimates.

The differences within the two sets of models are striking. The relationship between leader popularity and target response is much stronger in two domestic contexts: for leaders with low levels of policy resources (column 2 ) and for leaders of more autocratic systems (column 5). Both of the conditional hypotheses (Hypothesis 5 and Hypothesis 6) are supported by the results. In the first model, which estimates the effect of leader popularity on leaders with low levels of policy resources (column 2), the relationship between leader popularity and target response is negative and statistically significant. Comparing the results with the model presented in column 1, the size of the coefficient is much larger for the indicator of leader popularity. For leaders with high levels of policy resources (column 3), there is no systematic relationship between leader popularity and target response. Thus, the effect of changes in popularity on the probability that a leader will respond with force depends on the policy resources available to that leader. The last two columns in Table 1 (4 and 5) present the estimates of the models that evaluate the relationship between leader popularity and target response for domestic structures that are less autocratic and more autocratic, respectively. As expected, leader popularity has a stronger negative effect on the probability that the target will respond with force in more autocratic states (column 5) than it does in less autocratic states (column 4). ${ }^{21}$

The effects of the systemic variables also vary by domestic context,

\footnotetext{
${ }^{21}$ One objection to this analysis is that democratic leaders only use diversionary tactics on, or near, election times. To investigate this possibility, I analyzed all the disputes between 1955 and 1976 involving France, Germany, Great Britain, Israel, Japan, the Netherlands, and the United States, and calculated the maximum number of months that remained until
} 
although the results are not consistent. While there appears to be no systematic difference in the effect of the level of hostility of the initiator on target response across levels of autocracy, variations in levels of policy resources dramatically affect this relationship. In the original model, the relationship between the hostility of the initiator and target response was positive and significant well beyond the $p<.01$ level. However, the estimates in columns 2 and 3 indicate that the relationship only holds for leaders with low levels of policy resources. For leaders with an abundance of policy resources, the level of hostility of the initiator has no appreciable influence on their responses.

The effect of the relative capability of the target on the probability of the use of force is similarly affected by variations in domestic context. It has a significant effect in two contexts: on leaders with relatively low levels of policy resources and on leaders of more autocratic systems. On the other hand, leaders who possess high levels of policy resources and leaders of less autocratic systems appear to be relatively unaffected by relative capabilities.

How much of a difference do these factors make in the probability that the target responds with force? Table 2 reports the shifts in the cumulative normal probability distribution across selected values of the three key explanatory variables for the basic and constrained models. ${ }^{22}$ The first five rows in Table 2 display the shifts in the cumulative normal probability by level of hostility for each of the models estimated in Table 1. Compared with the other two key independent variables (see below), the level of hostility of the initiator has the strongest, most consistent effect on the probability that the target responds with force. For the basic model (column 1), if an initiator threatens to use force, the probability that the target will respond with force decreases by $28.4 \%$. On the other hand, if the initiator uses force, the probability that the target reciprocates increases by $6.4 \%$. Columns 2 through 5 present the effects of initiator hostility on the probability of the use of force by domestic context. These estimates reflect the differences highlighted in the discussion of Table 1 . Specifically, the level of hostility of the initiator has a fairly consistent effect across three of the four domestic contexts. However, for leaders who possess high levels of policy resources

elections would be held from the time of the dispute. I then reestimated the model for more democratic states controlling for the maximum number of months that remained until elections would be held. The coefficient estimate for leader popularity was -1.74 , with a $t$-ratio of $0.988(N=75)$. Although the negative sign is of greater magnitude than the coefficient obtained in the model presented in column 5, Table 1, it is much smaller than the coefficient estimate for the more autocratic states. Moreover, the $t$-ratio is far from being significant at the $p<.05$ level using a two-tailed test.

${ }^{22}$ Wolfinger and Rosenstone (1980, Appendix C) provide a discussion of this procedure. 
Table 2. Changes in the Cumulative Normal Probability of the Use of Force for Key Explanatory Variables

\begin{tabular}{|c|c|c|c|c|c|}
\hline \multirow[b]{2}{*}{ Variable } & $\begin{array}{l}\text { Basic } \\
\text { Model }\end{array}$ & $\begin{array}{l}\text { Low Policy } \\
\text { Resources }\end{array}$ & $\begin{array}{c}\text { High Policy } \\
\text { Resources }\end{array}$ & $\begin{array}{c}\text { Low } \\
\text { Autocracy }\end{array}$ & $\begin{array}{c}\text { High } \\
\text { Autocracy }\end{array}$ \\
\hline & 1 & 2 & 3 & 4 & 5 \\
\hline \multicolumn{6}{|l|}{ Initiator's hostility level } \\
\hline \multicolumn{6}{|l|}{ Low } \\
\hline 2 & -.284 & -.371 & .009 & -.183 & -.415 \\
\hline 3 & -.129 & -.173 & .003 & -.079 & -.218 \\
\hline 4 & .064 & .080 & -.002 & .038 & .097 \\
\hline 5 & .252 & .298 & -.007 & .158 & .362 \\
\hline \multicolumn{6}{|l|}{ High } \\
\hline \multicolumn{6}{|c|}{ Target's relative capability } \\
\hline Initiator preponderant & .055 & .040 & -.023 & .019 & .075 \\
\hline Equal capabilities & -.002 & -.013 & -.010 & -.001 & -.013 \\
\hline Target preponderant & -.051 & -.059 & .001 & -.018 & -.090 \\
\hline \multicolumn{6}{|l|}{ Leader popularity } \\
\hline \multicolumn{6}{|l|}{ Low level } \\
\hline 10th percentile & .070 & .079 & -.097 & .038 & .098 \\
\hline 20th percentile & .042 & .048 & -.064 & .023 & .058 \\
\hline 30th percentile & .029 & .033 & -.047 & .016 & .038 \\
\hline 40th percentile & .011 & .013 & -.023 & .007 & .013 \\
\hline 50th percentile & .000 & .000 & -.006 & .001 & -.003 \\
\hline 60 th percentile & -.013 & -.015 & .015 & -.006 & -.023 \\
\hline 70th percentile & -.022 & -.026 & .031 & -.011 & -.037 \\
\hline 80th percentile & -.037 & -.043 & .056 & -.019 & -.059 \\
\hline 90th percentile & -.065 & -.077 & .109 & -.034 & -.102 \\
\hline High level & & & & & \\
\hline
\end{tabular}

(column 3), the level of hostility of the initiator has little, if any, effect on their foreign policy decisions.

The estimates for relative capability presented in Table 2 fail to provide support for either the balance-of-power hypothesis (Hypothesis 2) or the power-preponderance hypothesis (Hypothesis 3 ). Contrary to the expectations of both theories, when the initiator is preponderant, the probability that the target will respond with force increases by $5.5 \%$. On the other hand, in disputes where the target is preponderant, the probability that the leader responds with force declines by $5.1 \%$. In addition, the magnitude and direction of these effects vary by domestic context. For leaders with high levels of policy resources, power preponderance increases the probability of the use of force by approximately one-tenth of one percent. In contrast, for more autocratic leaders, power preponderance 
actually decreases the probability that they respond with force by about $9 \%$.

The evaluation of the independent effects of different levels of leader popularity on the probability that a leader responds with force is based on selected percentiles of the indicator of popularity. The first column of Table 2 presents the probit estimates for the basic model. For leaders at the tenth percentile (i.e., $90 \%$ of the other leaders have values that are greater), the probability of the use of force is $7 \%$ greater than it is for the baseline model. In contrast, for leaders at the ninetieth percentile, the probability of the use of force decreases by $6.5 \%$. These estimates are consistent with the expectations of Hypothesis 4.

The estimates for the constrained models (columns 2 through 5) provide a more nuanced presentation of the conditioning effects of domestic structures. Comparing the estimates in columns 2 and 3 for leaders at the tenth percentile, we note that low levels of policy resources increase the probability that they respond with force by approximately $8 \%$. In contrast, leaders with high levels of policy resources are approximately $10 \%$ less likely to respond with force.

The effect of domestic political structures on the propensity of leaders to employ diversionary tactics appears to be one of magnitude rather than sign. These are presented in columns 4 and 5. Looking again at leaders at the tenth percentile on the popularity scale, we note that leaders of less autocratic governments are about $4 \%$ more likely to use force, while leaders of more autocratic governments are about $10 \%$ more likely to use force. Moreover, the differences are consistent across levels of popularity. At high levels of popularity (ninetieth percentile), leaders are about $3 \%$ more likely to use force if they face relatively high political costs for the use of force. In contrast, leaders of more autocratic states tend to be about $10 \%$ less likely to use force when their popularity levels are high. ${ }^{23}$

\section{Conclusions}

The primary objective of this study was to specify and to evaluate the conditioning effects of domestic structures on the propensity of leaders to

\footnotetext{
${ }^{23}$ The results reported in Table 1 and Table 2 may be the product of changes in sample size rather than a function of the independent variables. The analyses began with 294 cases, but the constrained models presented in Table 1 restrict the test to as few as 66 cases. To investigate the possible biasing effects of sample size on the coefficient estimates I estimated two sets of 25 models, one consisting of 25 randomly selected subsamples of 65 cases (based on the number of cases in column 3, Table 1), and the other set consisting of 25 randomly selected subsamples of 175 cases (based on the number of cases in column 4, Table 1). The results, reported in the Appendix, indicate that the effect of sample size on the estimates reported above are minimal.
} 
use international conflict involvement to manipulate domestic audiences. I argued above that the different results obtained by the initial and recent evaluations of diversionary theory were the product of specification error, and not simply a function of research design. Instead, the relationship between leader popularity and the political use of force is conditioned by domestic structures. All three of the domestic-level hypotheses are supported by the data. Controlling for domestic political institutions and the level of policy resources, there is a significant negative relationship between leader popularity and the probability of the use of force. Moreover, a comparison of subsamples of the data supported both of the conditioning hypotheses: the lower the ability of society to remove a leader from power, the more likely the leader will be to abuse that power for personal gain; and the fewer the resources available to leaders to influence their domestic environment, the more likely they are to use foreign policy to pursue their political ambitions.

The support for the system level hypotheses is mixed. While the level of hostility of the initiator has a strong, positive effect on the response of the target, the estimates for the effect of relative capability are in the opposite direction predicted. Moreover, even the systemic variables are influenced by the domestic context in which the dispute took place. Leaders of states with low levels of policy resources are much more likely than leaders that enjoy higher levels of policy resources to respond to threats from abroad in kind. This provides additional evidence that domestic political arrangements act as a filter for the effects of the international system on foreign policies of states.

More generally, the analyses presented here support the arguments of Rosenau (1969) and Putnam (1988) that the macro-micro division in international relations is inappropriate, and that international politics is linkage politics. Leaders make foreign policy decisions based on a number of factors-domestic and international-and an accurate explanation of these decisions must take into account both levels of analysis.

While the general implications of this analysis are encouraging, the empirical results suggest a lacuna. On the one hand, the results suggest that the responses of leaders to military threats from abroad are relatively unaffected by popularity levels if they face high domestic political costs for using force or if they possess an abundance of policy resources. On the other hand, Ostrom and Job (1986), James and Oneal (1991) and Morgan and Bickers (1992) find a strong relationship between presidential popularity and the political use of force. The United States is not only highly democratic, its leaders also enjoy relatively high levels of policy resources. The differences between the findings of this study and others may be attributable to a number of factors, such as the different measures of leader popularity, 
or to the fact that previous studies looked at dispute initiation while this focuses on target responses in disputes. One useful direction for future research would be to examine both dispute initiation and target response for the United States using survey and economic indicators of popularity, and then compare the results.

A second useful avenue of research is to explore in greater detail the composition of ruling coalitions across states. According to Morgan and Bickers $(1992,33)$, "we should expect a leader faced with a loss of support or domestic turmoil to deal with the problem differently if the challenge is from within the ruling coalition than if it comes from outside groups." In combination with information on the structure of domestic political institutions and levels of policy resources, knowledge of the composition and interests of the ruling coalition will enhance our ability to explain foreign policy decisions.

Manuscript submitted 2 March 1994.

Final manuscript received 22 October 1994.

\section{APPENDIX A \\ Evaluating the Robustness of the Constrained Models}

To investigate the possible biasing effects of sample size on the coefficient estimates I estimated two sets of 25 models, one consisting of 25 randomly selected subsamples of 65 cases (based on the number of cases in column 3, Table 1), and the other set consisting of 25 randomly selected subsamples of 175 cases (based on the number of cases in column 4, Table 1). If the results presented in Table 1 are a function of sample size, we should expect approximately one half of the 25 models using the smaller sample $(N=65)$ to report positive coefficients for the variable popularity, while the other coefficients should have negative signs. In the set of large samples $(N=175)$, if there is no conditioning effect of autocracy on the relationship between leader popularity and target response, we would expect one half of the models estimated to produce coefficients which are smaller in magnitude than the one reported in Table 1, column 4 , and the other half should be greater in size. The estimates for the leader popularity coefficients are reported below. 


\begin{tabular}{|c|c|c|c|}
\hline \multicolumn{4}{|c|}{ Coefficient Estimates for the Small and Large Subsamples } \\
\hline \multirow{3}{*}{$\begin{array}{l}\text { Small sample }(N= \\
\text { Leader Popularity } \\
\text { Coefficient (t-value) }\end{array}$} & & \multicolumn{2}{|c|}{ Large sample $(N=175)$} \\
\hline & & Leader Popularity & \\
\hline & & Coefficient (t-value) & \\
\hline 1. $-1.06(0.37)$ & 14. $-6.07(1.70)$ & 1. $-2.12(1.25)$ & 14. $-2.74(1.72)$ \\
\hline 2. $-10.83 *(2.30)$ & 15. $-4.49(1.32)$ & 2. $-3.33 *($ & 15. $-3.62 *(2.16)$ \\
\hline 3. $-6.13(1.62)$ & 16. $-4.37(1.18$ & 3. $-0.19(0.14)$ & 16. $-0.82(0.57)$ \\
\hline 4. $-0.99(0.03)$ & 17. $-7.36^{*}$ & 4. -0.49 ( & 17. $-3.17(1$ \\
\hline 5. $-3.27(1.02)$ & 18. $-1.06(0.3$ & 5. $-3.08(1.90)$ & 18. $-4.34 *(2.52)$ \\
\hline 6. $-2.86(0.90)$ & 19. $-10.83 *(2.30)$ & 6. $-1.58(0.95)$ & 19. -3.5 \\
\hline 7. $-2.80(1.11)$ & 20. $-5.45(1$. & 7. $-2.24(1.56)$ & 20. $-2.10(1.26)$ \\
\hline 8. $-10.33 *(2.41)$ & 21. $-1.55(0$. & 8. $-3.48 *(2.23)$ & 21. $-2.75(1.75)$ \\
\hline 9. $-2.45(0.55)$ & 22. $-1.00(0.33)$ & 9. $-2.38(1.65)$ & 22. $-2.62(1.56)$ \\
\hline 10. $-10.99(2.74)$ & 23. $-0.59(0.17)$ & 10. $-3.31 *(2.04)$ & 23. $-2.31(1.42)$ \\
\hline 11. $-5.44(1.74)$ & 24. $-8.78 *(2.19)$ & 11. $-2.21(1.51)$ & 24. $-2.79(1.77)$ \\
\hline 12. $-1.73(0.53)$ & 25. $-2.73(0.80)$ & 12. $-3.73 *(2.33)$ & 25. $-3.41 *(2.07)$ \\
\hline 13. $-3.89(1.45)$ & & 13. $-3.34 *(2.06)$ & \\
\hline
\end{tabular}

Comparing the coefficients in columns 1 and 2 above with the results in columns 3 and 4 in Table 1, we note that none of the former is positive, suggesting that the conclusions drawn from Table 1 regarding the conditioning effects of levels of policy resources and autocracy are reasonably robust. If the results for countries with high levels of policy resources and low levels of autocracy are due to sample size, we should find positive coefficients in about one-half of the models in columns 1 and 2 above. Looking at the coefficients of the indicator of leader popularity for the larger sample (column 4, Table 1) compared with the results presented in columns 3 and 4 above, the results are not as strong, however they still provide support for the hypothesis. True, three out of the 25 models have coefficients which are smaller in size than the coefficients reported in Table 1. Moreover, one of the coefficients is similar in size, although slightly greater. However, the remaining coefficients for the variable of leader popularity all exceed the size of the coefficient reported in Table 1, column 5. Thus, while it is possible that the results are a function of sample size, the probability that this is in fact the case is rather low.

\section{REFERENCES}

Aldrich, John H. and Forrest D. Nelson. 1984. Linear Probability, Logit and Probit Models. Sage University Paper Series on Quantitative Applications in the Social Sciences, 07045. Newbury Park: Sage.

Beck, Nathaniel. 1991. "The Economy and Presidential Approval: An Information Theoretic Perspective." In Economics and Politics: The Calculus of Support, ed. Helmut Norpoth, 
Michael S. Lewis-Beck, and Jean-Dominique Lafay. Ann Arbor: The University of Michigan Press.

Blainey, Geoffrey. 1988. The Causes of War. 3rd edition. New York: Free Press.

Bollen, Kenneth A. 1990. "Political Democracy: Conceptual and Measurement Traps." Studies in Comparative International Development 25:7-24.

Brace, Paul and Barbara Hinckley. 1992. Follow the Leader: Opinion Polls and the Modern Presidents. New York: Basic Books.

Brody, Richard. and Benjamin Page. 1975. "The Impact of Events on Presidential Popularity: The Johnson and Nixon Administrations. In Perspectives on the Presidency, ed. A. Wildavsky. Boston: Little, Brown.

Brody, Richard. 1984. "International Crises: A Rallying Point for the President?" Public Opinion 6:41-60.

Bueno de Mesquita, Bruce. 1981. The War Trap. New Haven: Yale University Press.

Bueno de Mesquita, Bruce and David Lalman. 1992. War and Reason. New Haven: Yale University Press.

Bueno de Mesquita, Bruce, Randolph M. Siverson, and Gary S. Woller. 1992. "War and the Fate of Regimes." American Political Science Review 86:638-646.

Bueno de Mesquita, Bruce and Randolph M. Siverson. 1993. "War and the Survival of Political Leaders: A Comparative Analysis." Presented at the annual meeting of the American Political Science Association, Washington, DC.

Chan, Steve. 1984. "Mirror, Mirror, on the Wall ... Are the Freer Countries More Pacific?" Journal of Conflict Resolution 28:617-64.

Gaubatz, Kurt T. 1991. “Election Cycles and War.' Journal of Conflict Resolution 35:21244.

Gilpin, Robert. 1981. War and Change in World Politics. New York: Cambridge University Press.

Gochman, Charles S., and Russell Leng. 1983. "Realpolitik and the Road to War: An Analysis of Attributes and Behavior." International Studies Quarterly 27:97-120.

Gochman, Charles S. and Zeev Maoz. 1984. "Militarized Interstate Disputes, 18161976: Procedures, Patterns and Insights." Journal of Conflict Resolution 28:586615.

Gochman, Charles S. and Russell Leng. 1988. "Militarized Disputes, Incidents and Crises: Identification and Classification." International Interactions 14:157-63.

Gochman, Charles S. and Alan Ned Sabrosky. 1990. Prisoners of War? Nation-States in the Modern Era. Lexington, MA: Lexington Books.

Goodman, L. A., and W. H. Kruskal. 1954. "Measures of Association for Cross-classification." Journal of the American Statistical Association 49:732-64.

Gurr, Ted Robert. 1990. "POLITY II: Political Structures and Regime Change, 1800 1986." Inter-University consortium for Political and Social Research, University of Michigan.

Gurr, Ted Robert, Keith Jaggers, and Will Moore. 1989. Polity II Handbook. Boulder: University of Colorado Press.

Haas, Michael. 1968. “Social Change and National Aggressiveness, 1900-1960.” In Quantitative International Politics, ed. by J. David Singer. New York: Free Press.

Haas, Ernst B. and Allen S. Whiting. 1956. Dynamics of International Relations. New York: McGraw-Hill.

Hazelwood, L. 1973. "Externalizing Systemic Stress: International conflict as adaptive behavior.' In Conflict Behavior and Linkage Politics, ed. by J. Wilkenfeld. New York: David McKay.

Hibbs, Douglas. 1982. “The Dynamics of Political Support for American Presidents among 
Occupational Classes: A Dynamic Analysis." American Political Science Review 76:259-79.

Huth, Paul. 1988. Extended Deterrence and the Outbreak of War. New Haven: Yale University Press.

Huth, Paul, and Bruce M. Russett. 1988. "Deterrence Failure and Crisis Escalation.” International Studies Quarterly 32:29-46.

Jackman, Robert W. 1993. "Rationality and Political Participation." American Journal of Political Science 37:279-290.

James, Patrick. 1987. “Externalization of Conflict: Testing a Crisis-Based Model.' Canadian Journal of Political Science 20:573-98.

James, Patrick, and John Oneal. 1991. "The Influence of Domestic and International Politics on the President's Use of Force." Journal of Conflict Resolution 35:307-32.

Kant, Immanuel. 1977. The Philosophy of Kant: Immanuel Kant's Moral and Political Writings. Trans. C. Friedrich. New York: Modern Library.

Kegley, Charles Jr., Neil R. Richardson, and Gunter Richter. 1978. "Conflict at Home and Abroad." Journal of Politics 40:742-752.

Keohane, Robert O., ed. 1986. Neorealism and its Critics. New York: Columbia University Press.

Kirchgassner, Genhard. 1991. "Economic Conditions and the Popularity of West German Parties: Before and after the 1982 Government Change." In Economics and Politics: The Calculus of Support, ed. Helmut Norpoth, Michael S. Lewis-Beck, and Jean-Dominique Lafay. Ann Arbor: University of Michigan Press.

Lafay, Jean-Dominique. 1991. "Political Dyarchy and Popularity Functions: Lessons from the 1986 French Experience." In Economics and Politics: The Calculus of Support, eds. Helmut Norpoth, Michael S. Lewis-Beck, and Jean-Dominique Lafay, Ann Arbor: University of Michigan Press.

Leng, Russell J., and Hugh G. Wheeler. 1979. "Influence Strategies, Success, and War." Journal of Conflict Resolution 23:655-84.

Leng, Russell J. 1983. "When Will They Ever Learn? Coercive Bargaining in Recurrent Crises." Journal of Conflict Resolution 27:379-420.

Levy, Jack. 1988. "Domestic Politics and War." Journal of Interdisciplinary History 18:653-73.

- 1989. "The Diversionary Theory of War." In Handbook of war studies, ed. M. Midlarsky. Boston: Unwin Hyman.

Lindsay, James M., Lois W. Sayrs, and Wayne P. Steger. 1992. "The Determinants of Presidential Foreign Policy Choice." American Politics Quarterly 20:3-25.

Londregan, John B. and Keith T. Poole. 1990. "Poverty, the Coup Trap, and the Seizure of Executive Power." World Politics 42:151-83.

MacKuen, Michael B. 1983. "Political Drama, Economic Conditions, and the Dynamics of Presidential Popularity." American Journal of Political Science 27:165-92.

Maoz, Zeev, and Nasrin Abdolali. 1989. "Regime Types and International Conflict, 18161976." Journal of Conflict Resolution 33:3-36.

Maoz, Zeev, and Bruce Russett. 1992. "Alliance, Contiguity, Wealth and Political Stability: Is the Lack of Conflict Among Democracies a Statistical Artifact?' International Interactions 17:245-67.

Morgan, T. Clifton, and Kenneth N. Bickers. 1992. "Domestic Discontent and the External Use of Force.' Journal of Conflict Resolution 36:25-52.

Morgan, T. Clifton, and Sally Howard Campbell. 1991. "Domestic Structure, Decisional Constraints and War: So Why Kant Democracies Fight?' Journal of Conflict Resolution 35:187-211. 
Morgan, T. Clifton, and Valerie Schwebach. 1992. "Take Two Democracies and Call Me in the Morning: A Prescription for Peace?' International Interactions 17:305-20.

Morgenthau, Hans J. 1967. Politics among Nations: The Struggle for Power and Peace, New York: Knopf.

Moul, William. 1988. "Balances of Power and the Escalation to War of Disputes among the European Great Powers, 1815-1939: Some Evidence." American Journal of Political Science 32:241-75.

Mueller, John. 1973. War, Presidents, and Public Opinion. New York: Wiley.

Nagler, Jonathan. 1991. "The Effect of Registration Laws and Education on U.S. Voter Turnout." American Political Science Review 85:1393-1406.

Norpoth, Helmut. 1991. "The Popularity of the Thatcher Government: A Matter of War and Economy."' In Economics and Politics: The Calculus of Support, ed. Helmut Norpoth, Michael S. Lewis-Beck, and Jean-Dominique Lafay. Ann Arbor: University of Michigan Press.

Organski, A.F.K. 1968. World Politics. New York: Knopf.

Organski, A.F.K., and Jacek Kugler. 1980. The War Ledger. Chicago: University of Chicago Press.

Ostrom, Charles, and Brian Job. 1986. "The President and the Political Use of Force." American Political Science Review 80:541-66.

Putnam, Robert. 1988. "Diplomacy and Domestic Politics: The Logic of Two-level Games.' International Organization 42: 427-60.

Richardson, Lewis F. 1960. Statistics of Deadly Quarrels. Pittsburgh: Boxwood Press.

Riker, William. 1990. "Political science and rational choice." In Perspectives on Positive Political Economy, ed. Alt, James and Kenneth Shepsle. Cambridge: Cambridge University Press.

Rosenau, James N. 1969. Linkage Politics. New York: Free Press.

Rummel, Rudolph. 1963. "Dimensions of Conflict Behavior within and Between Nations. Yearbook of the Society for General Systems 8:1-50.

Russett, Bruce. 1987. "Economic Changes as a Cause of International Conflict." In Peace, Defence and Economic Analysis, ed. by Christian Schmidt and Frank Blackaby. London: Macmillan.

Russett, Bruce. 1990. "Economic Decline, Electoral Pressure, and the Initiation of International Conflict.' In Prisoners of War?, ed. Charles Gochman and Alan Ned Sabrosky. Lexington: Lexington Books.

Siverson, Randolph M. and Michael Tennefoss. 1982. "Interstate Conflicts, 1815-1965." International Interactions 9: 147-78.

- 1984. "Power, Alliance and the Escalation of International Conflict, 1815-1965." American Political Science Review 78: 1057-69.

Siverson, Randolph M. and Harvey Starr. 1994. "Regime Change and the Restructuring of Alliances." American Journal of Political Science 38:145-61.

Small, Melvin and J. David Singer. 1976. "The War-Proneness of Democratic Regimes." Jerusalem Journal of International Relations 1:41-64.

. 1982. Resort to Arms: International and Civil Wars, 1816-1980. Beverly Hills: Sage.

Stohl, Michael. 1980. "The Nexus of Civil and International Conflict." In Handbook of Political Conflict: Theory and Research, ed. Ted Robert Gurr. New York: Free Press.

Summers, Robert, and Alan Heston. 1988. "A New Set of International Comparisons of Real Product and Price Levels for 130 Countries 1950-1985.' Review of Income and Wealth 34:1-25. 
Tanter, Raymond. 1966. "Dimensions of Conflict Behavior within and Between Nations, 1958-1960.' Journal of Conflict Resolution 10:41-64.

United Nations. Various Years. Statistical Yearbook. New York: United Nations.

United States Department of Health and Human Services. 1983. Social Security Programs Throughout the World. Washington, DC: U.S. Government Printing Office.

Waltz, Kenneth. 1959. Man, the State and War. New York: Columbia University Press. - 1979. Theory of International Politics. Reading, MA: Addison-Wesley. 1986. "Anarchic Orders and Balances of Power." In Neorealism and its Critics, ed. Robert O. Keohane. New York: Columbia University Press.

Weede, Erich. 1984. "Democracy and War Involvement." Journal of Conflict Resolution 28:649-64.

Wilkenfeld, Jonathan. 1968. “Domestic and Foreign Conflict Behavior of Nations." Journal of Peace and Research 1:56-69.

. 1972. "Models for the Analysis of Foreign Conflict Behavior of States.' In Peace, War and Numbers, ed. B. Russett. Beverly Hills, CA: Sage.

Wilkenfeld, Jonathan and Dina Zinnes. 1973. "A Linkage Model of Domestic Conflict Behavior." In Conflict Behavior and Linkage Politics, ed. Jonathan Wilkenfeld. New York: David McKay.

Wolfinger, Raymond E., and Steven J. Rosenstone. 1980. Who Votes? New Haven: Yale University Press.

Wright, Quincy. 1965. A Study of International Relations. New York: Appleton.

Zinnes, D., and J. Wilkenfeld. 1971. "An Analysis of Foreign Conflict Behavior of Nations.” In Comparative Foreign Policy, ed. W. Hanreider. New York: David McKay. 